\title{
THE RELATIONSHIP OF THE AGE OF RABBIT ERYTHROCYTES TO THE EFFECTS OF INOSINE ON THEIR OSMOTIC RESISTANCE ${ }^{1,2}$
}

\author{
By ERNST R. JAFFÉ,3 GRACE A. VANDERHOFF, BERTRAM A. LOWY, \\ AND IRVING M. LONDON \\ (From the Departments of Medicine and Biochemistry, Albert Einstein College of Medicine \\ and the Bronx Municipal Hospital Center, New York, N. Y.)
}

(Submitted for publication April 30, 1958; accepted May 22, 1958)

Several recent publications have described physical, chemical and biological differences between young erythrocytes, including reticulocytes, and mature erythrocytes of man and other species. Reticulocytes and young erythrocytes of the rabbit have been shown to contain more potassium and sodium, to have a greater cell volume and to have a lower density than the older cells (2). Differential centrifugation and radioiron labeling have been employed to demonstrate the increase in density with in vivo ageing of human erythrocytes $(3,4)$, and it was noted that after centrifugation the cells of the lower layers contained less water, potassium, chloride and bicarbonate (5). Differences in electrolyte composition had been observed previously on analyzing separate layers of human erythrocytes obtained on centrifugation (6). Further evidence has been provided that rabbit reticulocytes have an intact tricarboxylic-acid cycle and cytochrome system which are not present in mature erythrocytes (7). Increased cholinesterase activity has been demonstrated in the reticulocyte-rich upper layer of cells of centrifuged blood of rats, rabbits and man (8, 9 ), and a decline in cholinesterase and catalase activity with in vivo ageing of human erythrocytes has been observed (10). Immature erythrocytes of rabbits (2) and man $(11,12)$ appear to be

\footnotetext{
1 This work was presented in part at the Forty-Ninth Annual Meeting of the American Society for Clinical Investigation at Atlantic City, N. J., May 6, 1957 (1).

2 The work of this laboratory, of which these studies form a part, has been supported by grants from the Office of Naval Research [Contract Nonr-1765 (00)], the National Heart Institute of the National Institutes of Health, United States Public Health Service (Grant H-2803), the American Cancer Society, and the Atomic Energy Commission [Contract AT (30-1) 1855].

${ }^{3}$ Fellow of the National Foundation for Infantile Paralysis, 1955-1957.
}

more resistant to hemolysis in hypotonic media than are the older erythrocytes. Diminished glucose-6-phosphate dehydrogenase and 6-phosphogluconic dehydrogenase activities have been found in osmotically sensitive human erythrocytes as compared to these enzymatic activities in the osmotically resistant younger cells (11).

In studies on the relationship of metabolic activity of the erythrocyte to its structural integrity, the resistance of fresh human erythrocytes to osmotic stress has been found to be enhanced after incubation of the erythrocytes with certain purine nucleosides (13). This phenomenon was associated with a considerable uptake and further metabolism of the ribose moiety of the effective purine ribosides (14). The present report is concerned with the influence of in vivo ageing of rabbit erythrocytes upon the effect of the purine riboside, inosine, on osmotic resistance. Glycine-2- $\mathrm{C}^{14}$ was administered to a series of rabbits and, at intervals during the life span of the isotopically labeled erythrocytes, the effect of inosine on the osmotic resistance of the erythrocytes of different ages was determined.

\section{MATERIALS AND METHODS}

Adult male white New Zealand rabbits weighing 4.5 to $5.0 \mathrm{Kg}$. were given three subcutaneous injections, totalling $10 \mathrm{ml}$. over a two to three hour period, of glycine-2- $C^{14}$ in isotonic sodium chloride solution containing $0.032 \mathrm{mM}$ per $\mathrm{ml}$. with a specific activity of $625 \mu \mathrm{c}$. per $\mathrm{mM}$. At intervals of $4,8,46$ and 60 days after injection one of the rabbits was heparinized and exsanguinated, and the blood was collected in acid-citratedextrose solution (Cutter Laboratories, National Institutes of Health Formula B) in the proportion of four volumes of blood to one volume of acid-citrate-dextrose. The blood was centrifuged immediately and the plasma and buffy coat were removed. The erythrocytes were washed three times in isotonic sodium phosphate buffer, $\mathrm{pH} 7.3$, with centrifugation. Twenty-two per cent sus- 
pensions of the thrice washed erythrocytes were incubated either in isotonic sodium phosphate buffer alone or in buffer containing inosine in a final concentration of $\mathbf{1 5}$ micromoles per ml. of suspension for two hours at $37^{\circ} \mathrm{C}$. Following incubation, the erythrocytes were washed twice and subjected to hypotonic lysis by the method previously described (13), except that $16 \mathrm{ml}$. aliquots of each suspension were added to $64 \mathrm{ml}$. portions of sodium phosphate buffer ( $\mathrm{pH} 7.3)$ solutions of varying hypotonicity and to distilled water. Hypotonic solutions were so selected that the extent of lysis in the control and inosinetreated erythrocyte suspensions was comparable. The supernatant hemolysates were aspirated carefully after centrifugation, and the extent of hemolysis was calculated from the amount of hemoglobin liberated as measured by the optical density at $541 \mathrm{~m} \mu$ determined in a Beckman DU spectrophotometer and related to the distilled water sample whose hemolysis was taken as 100 per cent.

Duplicate portions of the hemolysates were diluted ten or fifteen times with unlabeled hemoglobin obtained from washed erythrocytes of rabbits of the same strain. A total of 2 to $3 \mathrm{Gm}$. of hemoglobin was precipitated by the addition of the hemolysates diluted with carrier hemoglobin to two and a half volumes of acetone. This dilution procedure was found to be accurate to within about 3 per cent. Hemin was extracted from the precipitated hemoglobin with three portions $(100,75$ and $50 \mathrm{ml}$.) of 1.2 per cent hydrochloric acid in acetone with centrifugation and filtration by a modification of the Anson and Mirsky procedure (15). Hemin was isolated in crystalline form by methods previously reported (16) and known to yield hemin of constant specific activity upon repeated crystallization. The radioactivity of the hemin (29 \pm 1 mg.) was determined at infinite thickness in teflon planchets with a center well $1 \mathrm{~cm}$. in diameter in a Nuclear-Chicago gas flow counter with a micromil window, model No. D-47. The counting error did not exceed 4 per cent.

\section{RESULTS AND DISCUSSION}

The influence of the age of rabbit erythrocytes upon their resistance to osmotic lysis is reflected

TABLE I

The influence of the age of rabbit erythrocytes on 1) osmotic resistance and 2) the effect of inosine on osmotic resistance *

\begin{tabular}{|c|c|c|c|c|c|}
\hline \multicolumn{3}{|c|}{ Phosphate control } & \multicolumn{3}{|c|}{ Inosine treated } \\
\hline $\begin{array}{l}\text { Per cent of } \\
\text { isotonicity } \\
\quad 1\end{array}$ & $\begin{array}{c}\text { Per cent } \\
\text { hemolysis } \\
2\end{array}$ & $\begin{array}{l}\text { Specific } \\
\text { activityt } \\
\mathbf{3}\end{array}$ & $\begin{array}{l}\text { Per cent of } \\
\text { isotonicity } \\
4\end{array}$ & $\begin{array}{c}\text { Per cent } \\
\text { hemolysis } \\
5\end{array}$ & $\begin{array}{l}\text { Specific } \\
\text { activityt } \\
6\end{array}$ \\
\hline \multicolumn{6}{|c|}{4 days after glycine-2-C 14} \\
\hline $\begin{array}{r}44 \\
43 \\
42 \\
41 \\
40 \\
0\end{array}$ & $\begin{array}{r}34 \\
43 \\
51 \\
57 \\
66 \\
100\end{array}$ & $\begin{array}{r}701 \pm 4 \\
820 \pm 6 \\
925 \pm 20 \\
938 \pm 12 \\
1,018 \pm 38 \\
1,285\end{array}$ & $\begin{array}{r}42 \\
41 \\
40 \\
39 \\
38 \\
0\end{array}$ & $\begin{array}{r}35 \\
40 \\
50 \\
58 \\
69 \\
100\end{array}$ & $\begin{array}{r}500 \pm 2 \\
544 \pm 4 \\
638 \pm 12 \\
740 \pm 15 \\
868 \pm 12 \\
1,325 \pm 15\end{array}$ \\
\hline \multicolumn{6}{|c|}{8 days after glycine-2-C ${ }^{14}$} \\
\hline $\begin{array}{l}38 \\
37 \\
36 \\
35\end{array}$ & $\begin{array}{l}33 \\
40 \\
46 \\
55\end{array}$ & $\begin{array}{l}1,118 \pm 1 \\
1,185 \pm 15 \\
1,295 \pm 15 \\
1,375 \pm 5\end{array}$ & $\begin{array}{l}36 \\
35 \\
34 \\
33 \\
32\end{array}$ & $\begin{array}{l}33 \\
38 \\
43 \\
51 \\
57\end{array}$ & $\begin{array}{r}795 \pm 0 \\
836 \pm 11 \\
898 \pm 28 \\
968 \pm 12 \\
1,082 \pm 22\end{array}$ \\
\hline 0 & 100 & $1,655 \pm 30$ & 0 & 100 & 1,720 \\
\hline \multicolumn{6}{|c|}{46 days after glycine-2-C } \\
\hline $\begin{array}{r}43 \\
42 \\
41 \\
40 \\
39 \\
0\end{array}$ & $\begin{array}{r}34 \\
46 \\
53 \\
60 \\
67 \\
100\end{array}$ & $\begin{array}{r}810 \pm 10 \\
810 \pm 30 \\
805 \pm 15 \\
865 \pm 25 \\
865 \pm 25 \\
1,040\end{array}$ & $\begin{array}{r}41 \\
40 \\
39 \\
38 \\
37 \\
0\end{array}$ & $\begin{array}{r}40 \\
48 \\
53 \\
61 \\
69 \\
100\end{array}$ & $\begin{array}{r}845 \pm 25 \\
895 \pm 5 \\
905 \pm 15 \\
910 \pm 30 \\
900 \pm 0 \\
1,072\end{array}$ \\
\hline \multicolumn{6}{|c|}{60 days after glycine- $2-C^{14}$} \\
\hline $\begin{array}{r}43 \\
42 \\
41 \\
40 \\
0\end{array}$ & $\begin{array}{r}32 \\
38 \\
48 \\
59 \\
100\end{array}$ & $\begin{array}{l}1,312 \pm 8 \\
1,245 \pm 15 \\
1,225 \pm 5 \\
1,215 \pm 35 \\
1,360\end{array}$ & $\begin{array}{r}41 \\
40 \\
39 \\
38 \\
0\end{array}$ & $\begin{array}{r}36 \\
48 \\
54 \\
62 \\
100\end{array}$ & $\begin{array}{l}1,420 \pm 10 \\
1,315 \pm 15 \\
1,340 \pm 10 \\
1,305 \pm 5 \\
1,388\end{array}$ \\
\hline
\end{tabular}

* Extent of hemolysis in hypotonic phosphate buffer and specific activity of hemin from lysates of rabbit erythrocytes incubated for two hours at $37^{\circ} \mathrm{C}$. in isotonic sodium phosphate buffer alone or with 15 micromoles inosine per ml. of incubation suspension.

† Counts per minute above background per standard planchet $(29 \pm 1 \mathrm{mg}$. hemin) corrected for dilution with carrier hemoglobin \pm deviation from the mean. 
in the data of Table I, Columns 1 to 3 . At any one time after administration of glycine-2- $\mathrm{C}^{14}$, random lysis of erythrocytes in the various hypotonic phosphate buffer solutions would have yielded hemin of the same specific activity regardless of the extent of hemolysis, i.e., the radioactivity of the hemin isolated from the hemoglobin of the lysed erythrocytes would have been the same as that observed in an aliquot of the whole suspension as represented by the 100 per cent hemolysis samples. Actually, however, in the experiments performed four and eight days after injection of the labeled glycine, the specific activity of the hemin at points between 33 and 66 per cent hemolysis was only 55 to 83 per cent of that of the whole suspension. It is apparent, therefore, that the erythrocytes four or eight days of age and younger were more resistant to hypotonic lysis than the average of the total cell population.

In the experiment performed with the erythrocytes from the rabbit that received glycine-2-C ${ }^{14}$ 46 days earlier, the specific activity of the hemin from those cells which were lysed at various levels of hypotonicity was slightly less than that of the 100 per cent hemolysate. Therefore, these labeled cells were still somewhat more resistant to hypotonic lysis than the average of the whole cell population. After 60 days, the specific activity of the hemin at various degrees of lysis was similar to that observed at 100 per cent lysis.

These data demonstrate increased osmotic resistance of young erythrocytes when compared to the average of the entire cell population, and they are consistent with the findings reported recently from other laboratories $(2,11,12)$. The specific activities observed in the experiment at 60 days indicate that the cells of this age have a susceptibility to hemolysis essentially similar to that of the average of the total cell population. If these older cells have an increased susceptibility to lysis, one might expect, in the 60 day experiment, slightly greater specific activity in the hemin samples isolated from hemolysates in which the extent of hemolysis is less than 100 per cent, since at 60 days the erythrocytes are nearing the end of the expected life span of rabbit erythrocytes (17). It would be desirable, therefore, to investigate the osmotic resistance of old erythrocytes at ages greater than 60 days and at levels of lysis in which only a small fraction of the cells are destroyed.
In every instance, under conditions of comparable osmotic stress, the extent of hemolysis of inosine-treated erythrocytes was less than that of control erythrocytes (Table I, Columns 1, 2, 4 and $5)$. The finding that inosine enhances the osmotic resistance of rabbit erythrocytes is similar to that previously reported for human erythrocytes (13).

In the hemin isolated from hemolysates obtained from erythrocytes incubated with inosine four and eight days after the rabbits received labeled glycine, the specific activity was lower than that of the hemin of the control hemolysates at comparable levels of lysis (Table I, Columns 4 to 6). Figure 1 presents the ratios of the specific activity of the hemin from the inosine-treated erythrocytes to the specific activity of the hemin from the control erythrocytes at 40,50 and 60 per cent hemolysis as interpolated from curves of specific activity plotted against per cent hemolysis. If no preferential protection of isotopically labeled erythrocytes on incubation with inosine had occurred, these ratios would have been equal to unity. In the experiments performed with erythrocytes from rabbits injected with glycine-2-C ${ }^{14}$ four and eight days earlier, the ratios were 0.70

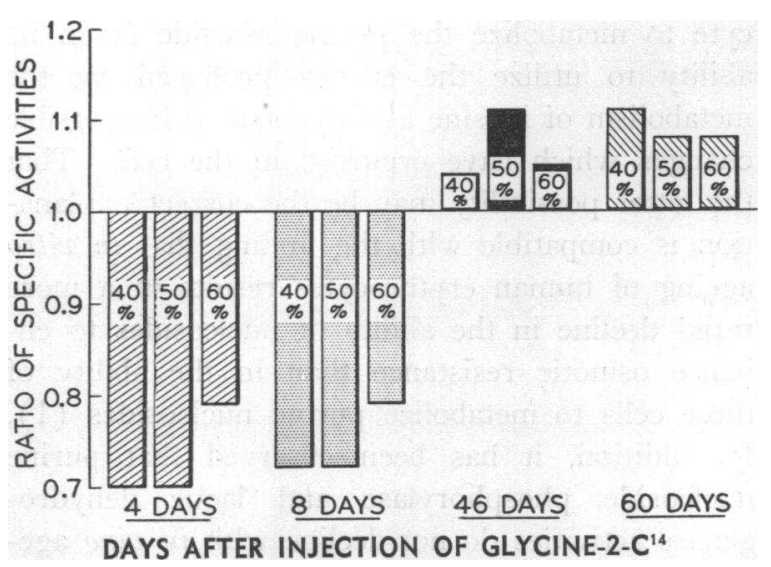

Fig. 1. Relationship of the Age of Rabbit Erythrocytes to The EfFect of Inosine on Their Osmotic FRAGILITY

Ratio $=\frac{\begin{array}{l}\text { Specific activity of hemin from lysates of inosine- } \\ \text { treated erythrocytes }\end{array}}{\begin{array}{l}\text { Specific activity of hemin from lysates of control } \\ \text { erythrocytes }\end{array}}$

Per cent refers to per cent hemolysis in hypotonic phosphate buffer solutions after incubation in isotonic sodium phosphate buffer alone or with inosine for two hours at $37^{\circ} \mathrm{C}$., as interpolated from curves of specific activity plotted against per cent hemolysis. 
to 0.79 . It is apparent, therefore, that rabbit erythrocytes four or eight days old and younger were preferentially protected against hypotonic lysis by incubation with inosine. After 46 and 60 days the ratios were 1.04 to 1.11 , findings which indicate that no preferential protection of the labeled cells had occurred. The ratios slightly greater than unity could conceivably be the result of some increased hemolysis of the labeled erythrocytes incubated with inosine, but more likely reflect the protection by incubation with inosine of the young, unlabeled erythrocytes.

The findings with inosine-treated rabbit erythrocytes are compatible with other observations that the effects of incubation with inosine are dependent upon metabolic activity of the erythrocyte. These effects include enhanced resistance to osmotic lysis $(13,18)$, increased organic phosphate esters within the cells (18), restoration of intracellular potassium $(18,19)$ and sodium concentrations (20), and perhaps slight prolongation of viability of in vitro stored erythrocytes $(18,21$, 22). The decline in the effect of inosine on the osmotic resistance of rabbit erythrocytes which have aged normally in vivo may indicate either a concomitant decline in the ability of the erythrocyte to metabolize the purine riboside or in its ability to utilize the energy produced by the metabolism of inosine as the result of irreversible changes which have occurred in the cell. That the latter possibility may be the correct explanation is compatible with the finding that in vitro ageing of human erythrocytes results in a more rapid decline in the ability of nucleosides to enhance osmotic resistance than in the ability of these cells to metabolize purine nucleosides (1). In addition, it has been observed that purine nucleoside phosphorylase and lactic dehydrogenase activities do not decline with in vivo ageing of human erythrocytes (23) and that purine nucleoside phosphorylase activity does not decrease in the erythrocytes surviving prolonged in vitro storage (24).

\section{SUMMARY AND CONCLUSIONS}

On labeling of rabbit erythrocytes in vivo with glycine-2-C ${ }^{14}$ it was demonstrated that: 1) Young erythrocytes are more resistant to hypotonic lysis than the average of the whole cell population, and
2) incubation with the purine nucleoside, inosine, for two hours at $37^{\circ} \mathrm{C}$. in isotonic sodium phosphate buffer, $\mathrm{pH} 7.3$, increases the resistance to osmotic stress of young erythrocytes much more than that of the average of the total cell population.

\section{REFERENCES}

1. Jaffé, E. R., Vanderhoff, G. A., Lowy, B. A., and London, I. M. The effect of nucleosides on osmotic resistance of mammalian erythrocytes in relation to the age of the cells (abstract). J. clin. Invest. 1957, 36, 903.

2. Chalfin, D. Differences between young and mature rabbit erythrocytes. J. cell. comp. Physiol. 1956, 47, 215.

3. Dreyfus, J.-C., Schapira, G., and Kruh, J. Fractionnement des hématies selon leur âge. Centrifugation d'hématies marquées par le fer radioactif. C. R. Soc. Biol. (Paris) 1950, 144, 792.

4. Borun, E. R., Figueroa, W. G., and Perry, S. M. The distribution of $\mathrm{Fe}^{\infty 0}$ tagged human erythrocytes in centrifuged specimens as a function of cell age. J. clin. Invest. 1957, 36, 676.

5. Borun, E. R. Differences in electrolyte composition and potassium exchange associated with in vivo aging of human erythrocytes. Clin. Res. Proc. 1957, 5, 142.

6. Keitel, H. G., Berman, H., Jones, H., and MacLachlan, E. The chemical composition of normal human red blood cells, including variability among centrifuged cells. Blood 1955, 10, 370.

7. Rubinstein, D., Ottolenghi, P., and Denstedt, O. F. The metabolism of the erythrocyte. XIII. Enzyme activity in the reticulocyte. Canad. J. Biochem. 1956, 34, 222.

8. Pritchard, J. A. Erythrocyte age and cholinesterase activity. Amer. J. Physiol. 1949, 158, 72.

9. Sabine, J. C. The cholinesterase of erythrocytes in anemias. Blood 1951, 6, 151.

10. Allison, A. C., and Burn, G. P. Enzyme activity as a function of age in the human erythrocyte. Brit. J. Haemat. 1955, 1, 291.

11. Marks, P. A. A relationship between human erythrocyte aging in vivo and the activities of glucose-6phosphate and 6-phosphogluconic dehydrogenases (abstract). J. clin. Invest. 1957, 36, 913.

12. Simon, E. R., and Topper, Y. J. Fractionation of human erythrocytes on the basis of their age. Nature (Lond.) 1957, 180, 1211.

13. Jaffé, E. R., Lowy, B. A., Vanderhoff, G. A., Aisen, P., and London, I. M. The effects of nucleosides on the resistance of normal human erythrocytes to osmotic lysis. J. clin. Invest. 1957, 36, 1498.

14. Lowy, B. A., Jaffé, E. R., Vanderhoff, G. A., Crook, L., and London, I. M. The metabolism of purine nucleosides by the human erythrocyte in vitro. J. biol. Chem. 1958, 230, 409. 
15. Anson, M. L., and Mirsky, A. E. Protein coagulation and its reversal. The preparation of insoluble globin, soluble globin and heme. J. gen. Physiol. 1930, 13, 469.

16. Kassenaar, A., Morell, H., and London, I. M. The incorporation of glycine into globin and the synthesis of heme in vitro in duck erythrocytes. J. biol. Chem. 1957, 229, 423.

17. Neuberger, A., and Niven, J. S. F. Haemoglobin formation in rabbits. J. Physiol. (Lond.) 1951, 112, 292.

18. Gabrio, B. W., Donohue, D. M., and Finch, C. A. Erythrocyte preservation. V. Relationship between chemical changes and viability of stored blood treated with adenosine. J. clin. Invest. 1955, 34, 1509.

19. Kahn, J. B., Jr., and Cohen, S. B. Effects of ribosides and related compounds on cation transport in cold- stored human erythrocytes. J. Pharmacol. exp. Ther. 1957, 120, 9.

20. Harris, E. J., and Prankerd, T. A. J. The effect of adenosine on the movement of sodium between erythrocytes and the suspension medium (abstract). Biochem. J. 1955, 61, xix.

21. Prankerd, T. A. J. Revival of stored blood with guanosine and its successful transfusion: Lancet 1956, 1, 469.

22. Lange, R. D., Escobar, M. R., and Crosby, W. H. In vitro and in vivo studies of acid-citrate-dextroseinosine (ACDI) as a blood preservative (abstract). J. Lab. clin. Med. 1956, 48, 919.

23. Marks, P. A., Johnson, A. B., and Hirshberg, E. Effect of age on the enzyme activity of erythrocytes. Proc. nat. Acad. Sci. (Wash.) In press.

24. Marks, P. A., Johnson, A. B., DeBellis, R., and Banks, J. Stability of metabolism of erythrocytes stored in vitro. Fed. Proc. 1958, 17, 269. 